\title{
Potentiality of the community Willingness for using desalination plants for the groundwater wells in Jericho Area - Palestine
}

\author{
Marwan Ghanem ${ }^{1}$, Sven Lübbecke ${ }^{2}$, Christine Schweder ${ }^{3}$ \\ ${ }^{1}$ Birzeit University, Ramallah, Palestine \\ marwan.ghanem2012@gmail.com \\ ${ }^{2}$ STULZ-PLANAQUA GmbH, Bremen, Germany \\ sven.luebbecke@stulz-planaqua.com \\ ${ }^{3}$ STULZ-PLANAQUA GmbH, Bremen, Germany \\ christine.schweder@stulz-planaqua.com
}

\begin{abstract}
Water shortage is one of the main issues in Jericho area in Palestine, hampering further development of agriculture. A higher amount of water suitable for irrigation would render a significant growth of the agricultural market and the associated branches possible and thus be of great economical advantage. Not only is the current water shortage problematic for farmers, but it is to be expected that it will increase in near future. More water is needed, but less is available due to less rainfall. Still, additional brackish water would be available, but its usage would endanger soil quality in the long run. Desalination is a possible solution. The study presented in this contribution is consists therefore of a field survey of 25 questionnaires was carried out for the analyses for the community acceptance towards using desalination units for saline and brackish water for agricultural irrigation. The average cost of one cubic meter of the desalinized water that is accepted by the participants of the survey for agricultural use is 0.25 Euro, which is equal or less than the current pumping costs for non-desalinated water. The majority of surveyed well owners estimate that their crop productivity will be increased by 40 to 60 percent after using the units. This will increase also the annual water consumption to its one third to one half more than its usual water consumption rate $(700-1200$ cubic meter for each dunum per year, 1 dunum $=1000$ $\mathrm{m}^{2}$ ). Variability in crop sorts will be added in addition to raw and cooked grown vegetables as well as of grown Palm trees. A majority of the farmers (95\%) thinks that the long-term use of saline water will destroy the fertility of the soil as well as the crop agricultural cycle in the area.
\end{abstract}

Key words: Desalination plants, Jericho, economic impact of irrigation

Council for Innovative Research

Peer Review Research Publishing System

Journal: International Journal of Management \& Information Technology

Vol. 5, No. 1

editor@cirworld.com

www.cirworld.com, member.cirworld.com 


\section{INTRODUCTION}

Water will play as the major limiting factor for economic development, for that reason, development of the water resources in Palestine is considered to be one of the top priorities for the Palestinian Authority. The increase in population and standards of living in the West Bank can place the available resources of water and their quality under a serious threat. The Jordan Valley is a fertile productive region, which constitutes $52 \%$ of the total irrigated land in the West Bank. It is described as the food basket of Palestine where citrus, bananas, date palms, vegetables and field crops are grown all over the year (MoA, 2012). Groundwater wells and springs originating from the Quaternary Aquifer System to the Upper and Lower Cenomanian aquifer systems form the main water resource in the Jordan Valley (Levni et al., 2008). The groundwater quality is threatened by the high chloride and sodium concentrations as well as the elevated concentrations of sulphate and nitrate in some of groundwater wells (Levni et al., 2008). The study area is the Jericho District, which is of $65 \mathrm{~km}^{2}$ and it is the lowest land on the earth with ground levels ranging between $200-400$ meters below sea level (bsl). The Jericho district is located in the eastern boundary of the West Bank, about $7 \mathrm{~km}$ to the west of the Jordan River. It has a desert climate, classified as arid, with hot summer and warm winter, while its water resources shapes its oasis character.

In the study area, there are 63 production wells tapping the Alluvial Aquifer (4.5 Mm³/year) (PWA, 2012). The depth of these wells range between 15 and $200 \mathrm{~m}$. Almost all water from wells and springs is used for irrigation. In the western and northwestern outside the study area, there are few deep wells and springs (23.3 $\mathrm{Mm}^{3} /$ year) discharging from the Cenomanian Aquifer. 26.5 Mm3/year (4.5 Mm3/year from alluvial wells and $22.0 \mathrm{Mm}^{3} /$ year from springs) is used for irrigation in the study area (PWA, 2012). The Quaternary Aquifer System in the study area could be divided into an upper alluvial layer and a lower low-permeable Lisan layer, which crops out in the eastern part of the study area (Marei and Vengosh, 2001).One of the major problems in Jericho area is the increasing of salinization of the groundwater. The high chloride limits the utilization of the aquifers for both domestic and agricultural purposes.

The objective of this study is to study the willingness of the well owner community of Jericho area to use the desalinized water from the groundwater aquifers.

\section{Methodology}

A field survey of 25 questionnaires was carried out in Jericho area - Palestine for the owners and farmers of the groundwater wells. The questionnaire aims to evaluate the farmer's acceptance to use Water Treatment technologies to reduce salinity of their groundwater source. The questionnaire considers variable constraints; water source, usage of water, land area, technologies used and the owners of the wells acceptance for desalinized treatment units. The personal questions targeting the age and, number of involved farmers and their education. Other questions about the ownership of land, planted land area, irrigated land, water irrigated type, irrigation kind, cropping type, current cost of the one cubic meter of water and the consumed irrigation water are queried. The export of the products in internal market and historical review of growing crop yields was studied. Their acceptance of using the desalinized treatment units of their wells was one of the major concern for the questions. The questionnaire analyses for the community acceptance towards using desalination units for saline and brackish water for agricultural irrigation was analyzed using the SPSS software.

\section{Results and Analyses Discussions}

Sixty percent of the sample owns their irrigated land, while the rest are in the category of sharing or renting land for agricultural purposes (Fig 1).

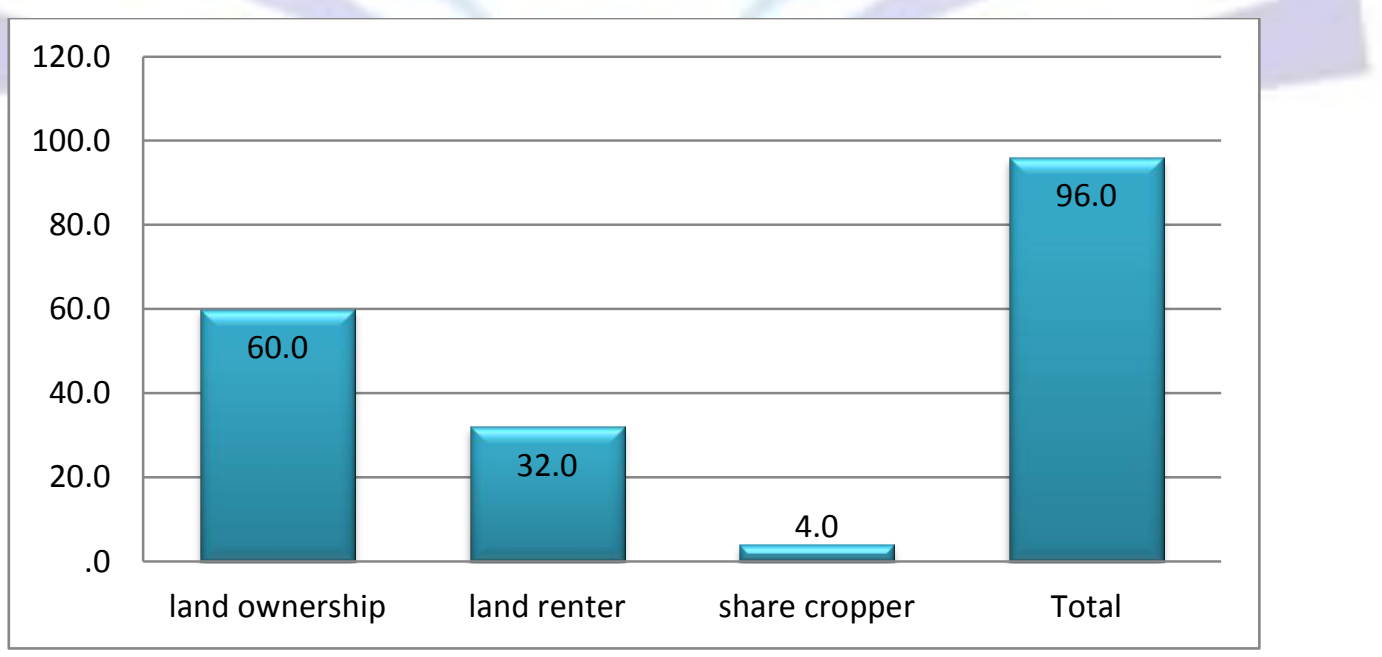

Fig. 1: Land ownership 
The majority of the surveyed sample having more than 15 dunums for irrigation of $88 \%$, while $84 \%$ of them having land planted area of the same area (Fig 2).

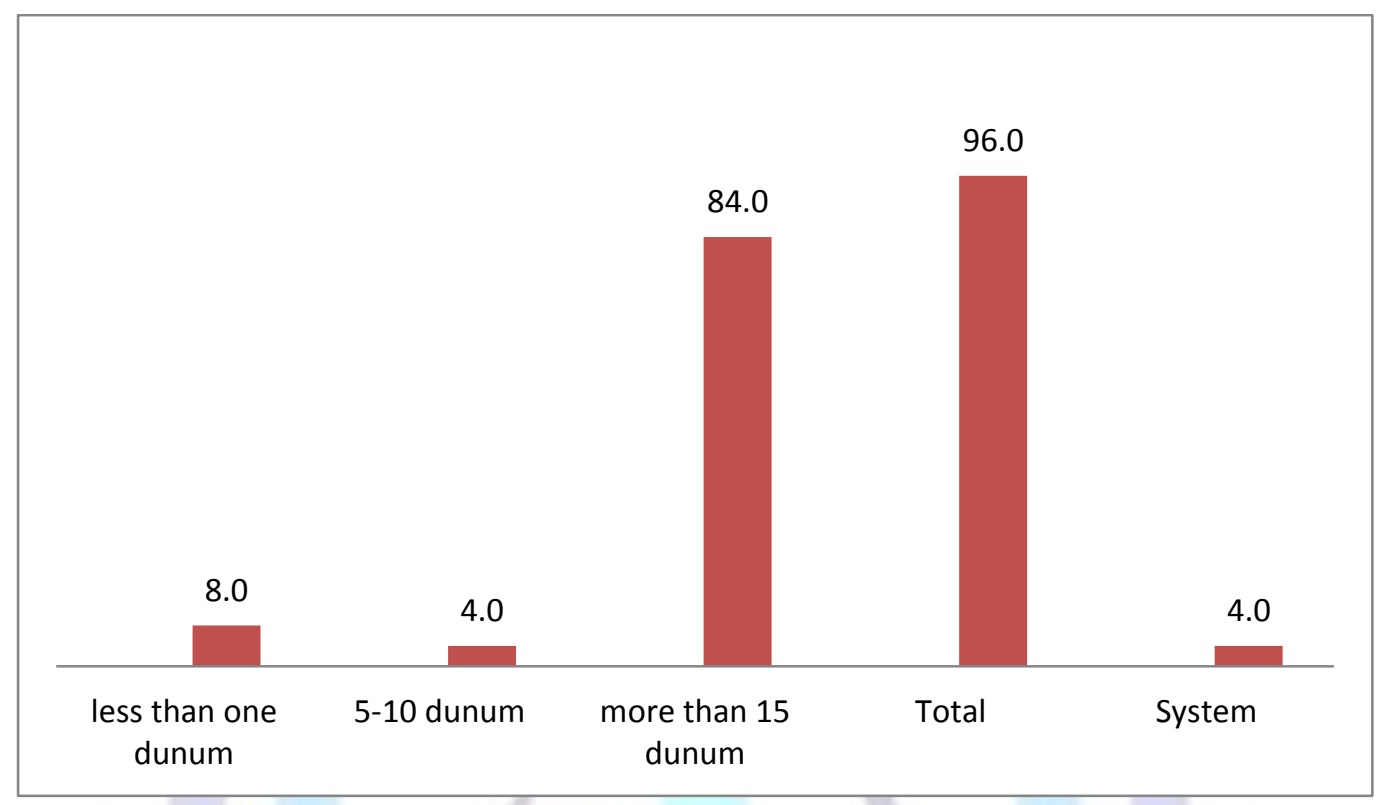

Fig. 2: Area of irrigated land.

The majority of the farmers are using the water of groundwater wells for irrigation and $4 \%$ of them are sharing this amount with spring water as well as other water sources. Eighty percent of the sample perform chemical analyses of their water. The cost of each one cubic meter of water used for irrigation is different from place to place and range between 0.5 NIS and $1 \mathrm{NIS}(0.1-0.2$ Euro) (Fig. 3). Only $32 \%$ have cost of water of below 0.1 Euro.

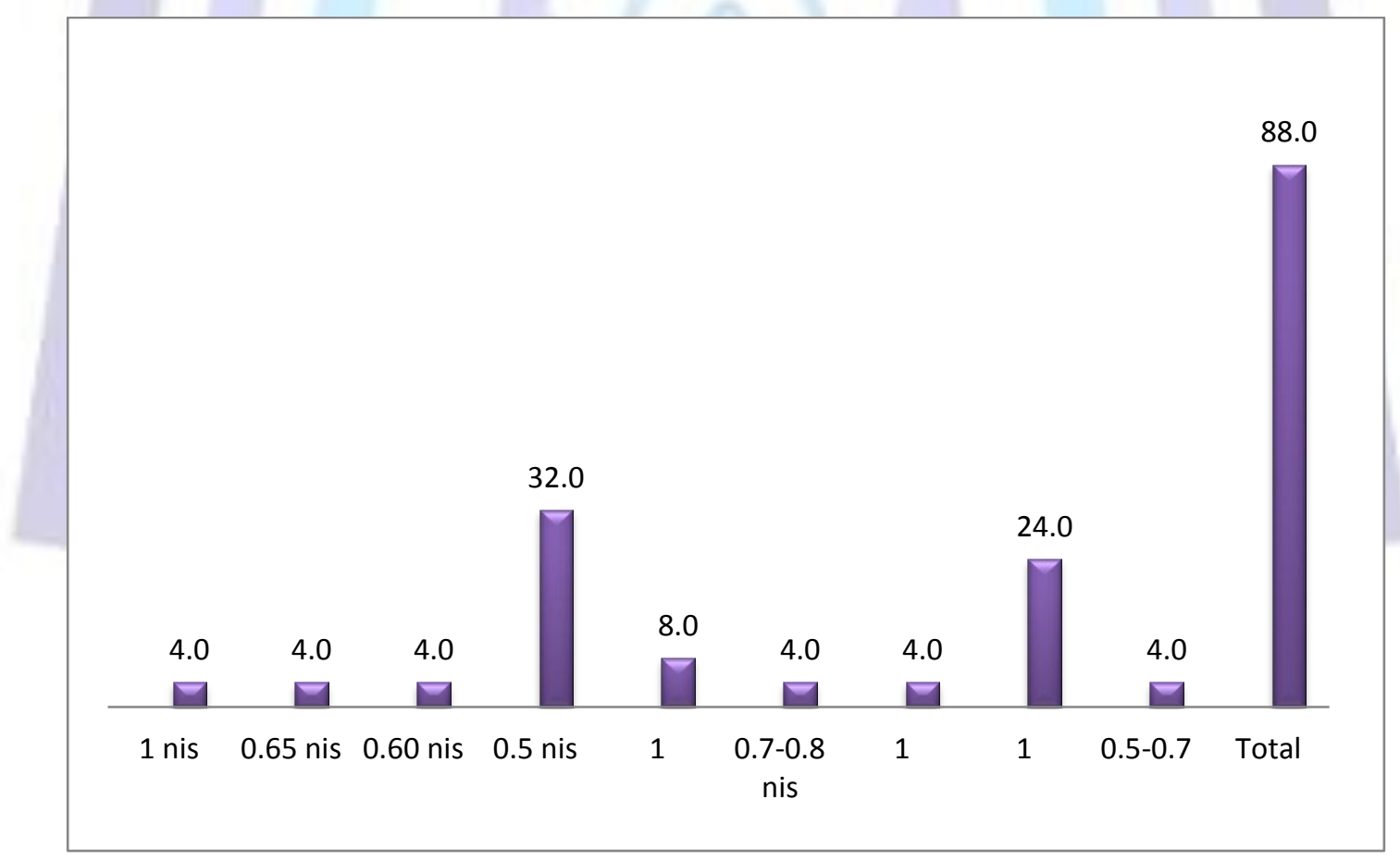

Fig. 3: The cost of one cubic meter of water used for irrigation from the well.

The average water consumed for the farms are ranging between 200 to 1200 cubic meters per dunum yearly. $44 \%$ of them are consuming water per dunum of $900-1200$ cubic meters (Fig. 4). Eighty percent of the farms are using water without any treatment. That means there is a need of using treatment facilities in order to improve their quality of cropping as the farmers also reported a decrease in copping quality. Nearly all of the farms are using drip irrigation, while only $4 \%$ are using sprinkler irrigation and all of them are using pipes to channel the water to their farms. 


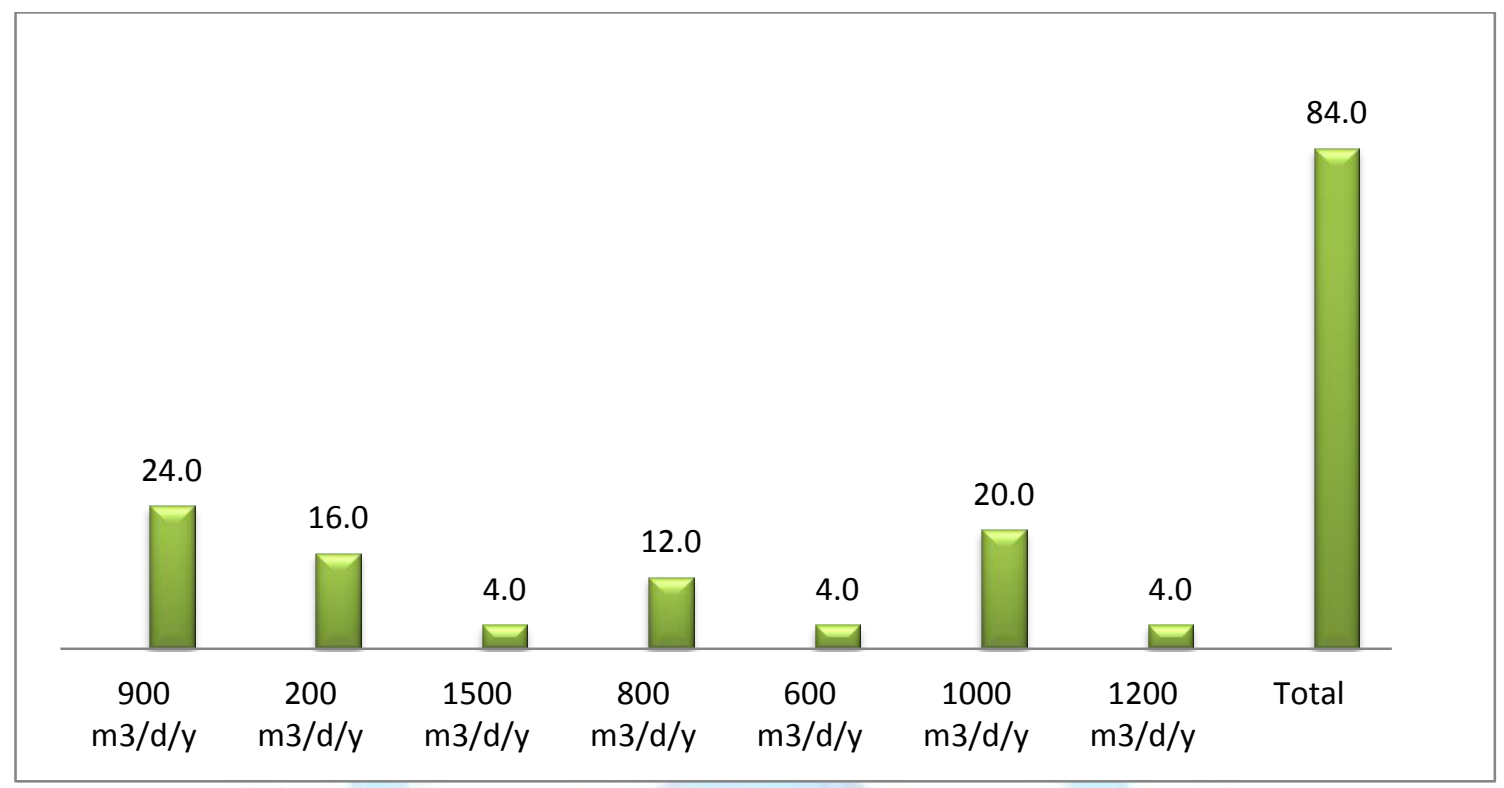

Fig. 4: The average water consumed for the farm per dunum from the well.

Forty percent of the sample is irrigated water for planting the agricultural crops and $28 \%$ of them are planting cooked vegetables. Planting vegetables is the major cropping in Jericho area, only $4 \%$ of them are planting fruit baring trees (Fig. 5 ). Some of the farms have animals and they use water from these wells for them, but $28 \%$ of them are using the spring water for them. The agricultural market is selling (76\%) of their crops and $84 \%$ was sold within the internal market. In regards that all of them are using groundwater, but $76 \%$ of them are answering that there is a shortage of water. They couldn't do any cropping development because of the water shortage and because of the well quotas for keeping the aquifer balance. In summer times it is clear that the need of water is much more than in winter seasons, because the cropping season is much more in the spring and summer seasons.

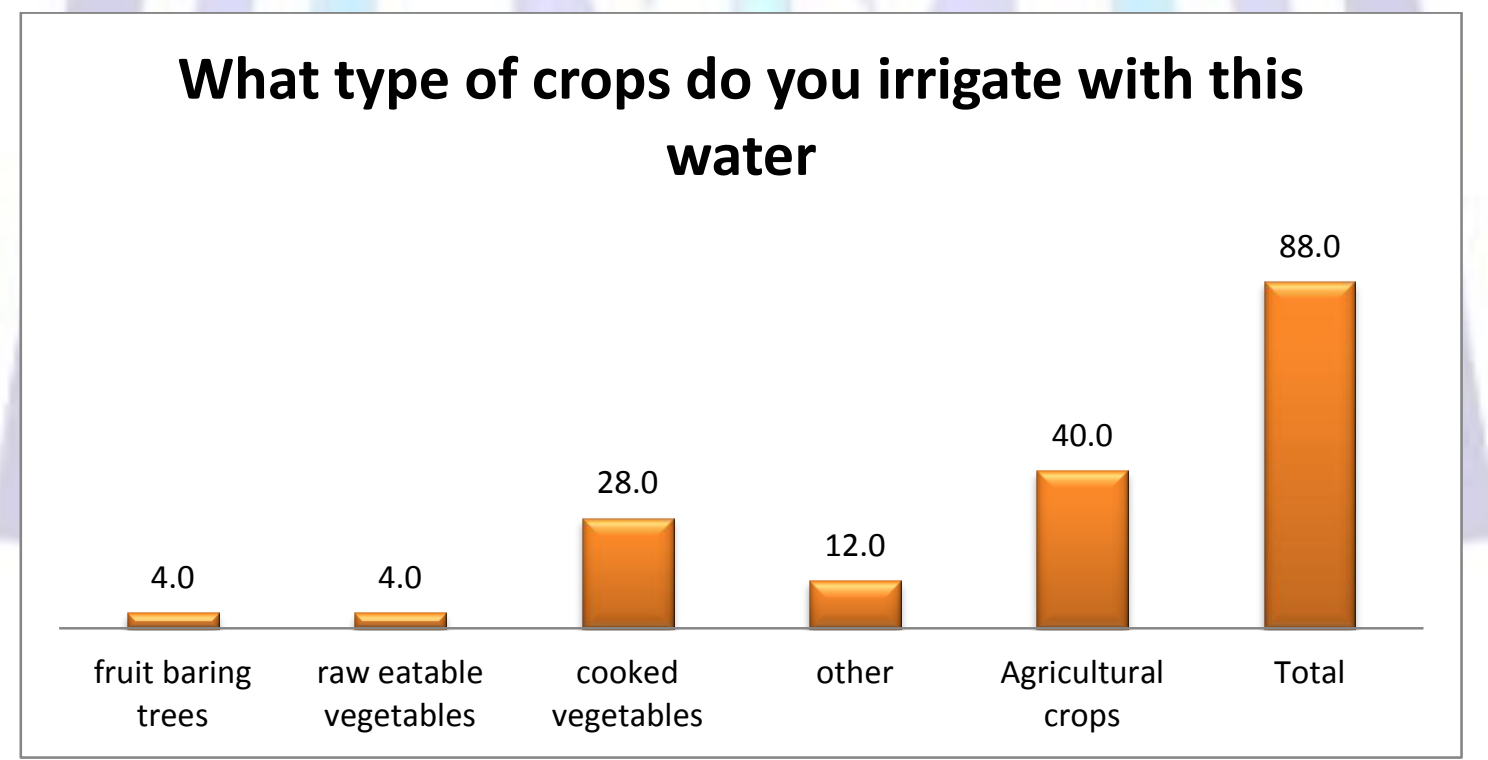

Fig. 5: Type of irrigated crops

In regards that there is no treatment of the saline water for this groundwater $68 \%$ of them are expecting that this is because of the price and the cost of the needed treatment. The majority of them expects that the treated cost of the saline water is more expensive than buying fresh water from springs. The spring water is limited and it is restricted to Ein Sultan spring. In order to open up new sources of water and to develop the agriculture in the area and to bring more qualitative cropping, treatment of saline water is necessary. $88 \%$ of them would accept costs of the treated saline water of 0.2 Euro per cubic meter, which is in regards to standard of living within the Jericho area (Fig. 6 ). Still, 60 percent of them are willing to pay for the 0.2 Euro per treated saline water. 


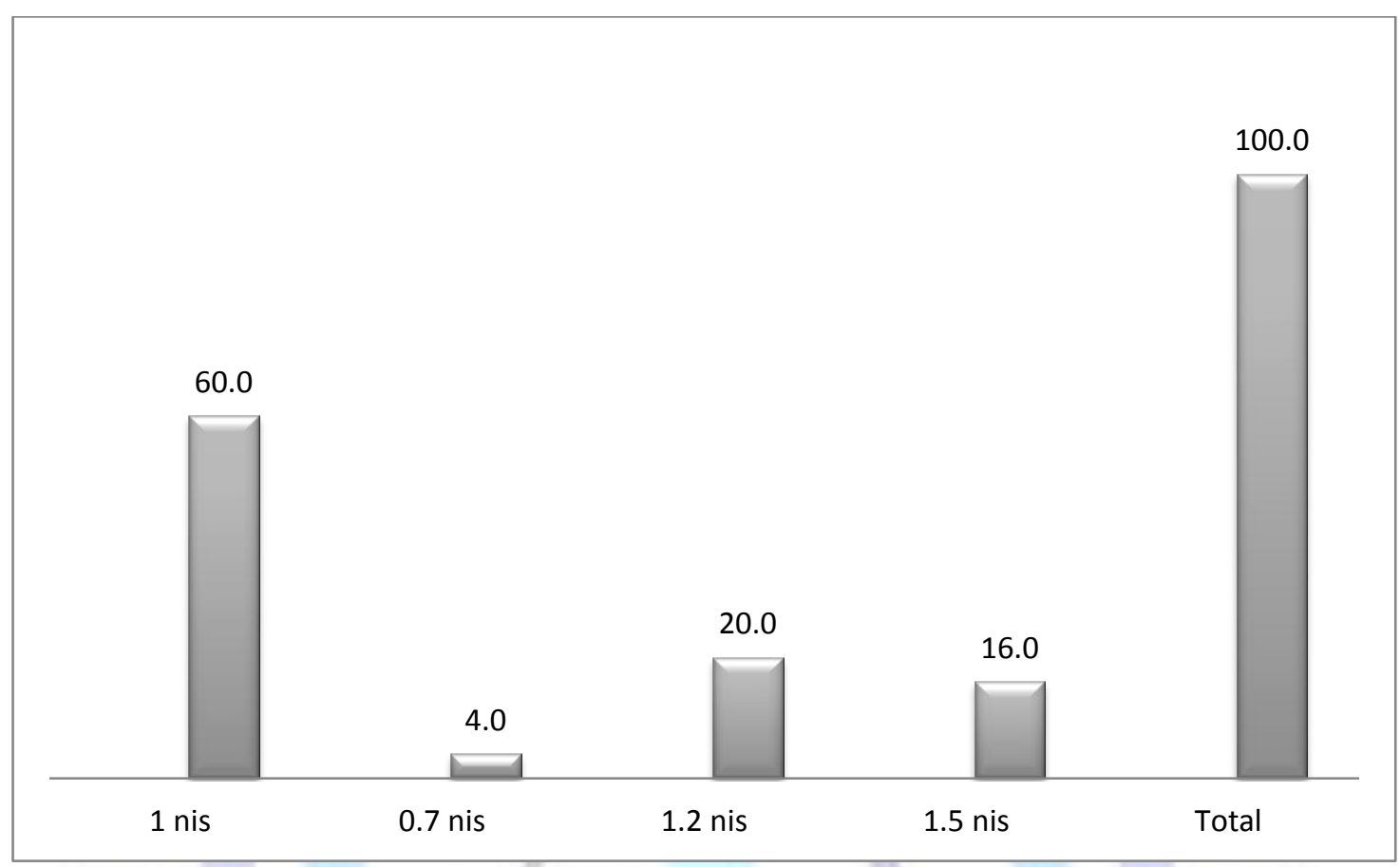

Fig. 6: The highest price questioned farmers are willing to pay for water used in irrigation (NIS/ cubic meter).

Nearly half $(44 \%)$ of them are expecting that having a desalinated water will increase the amount of their harvest by $40 \%$ (Figure 7). This low percentage is due to the fact that there is no example of the desalinated treatments in Jericho area (Fig. 7). $84 \%$ of them are agreeing that having such treatment facilities would results in planting different crops and this will develop their farms and fetch with higher prices in the market.

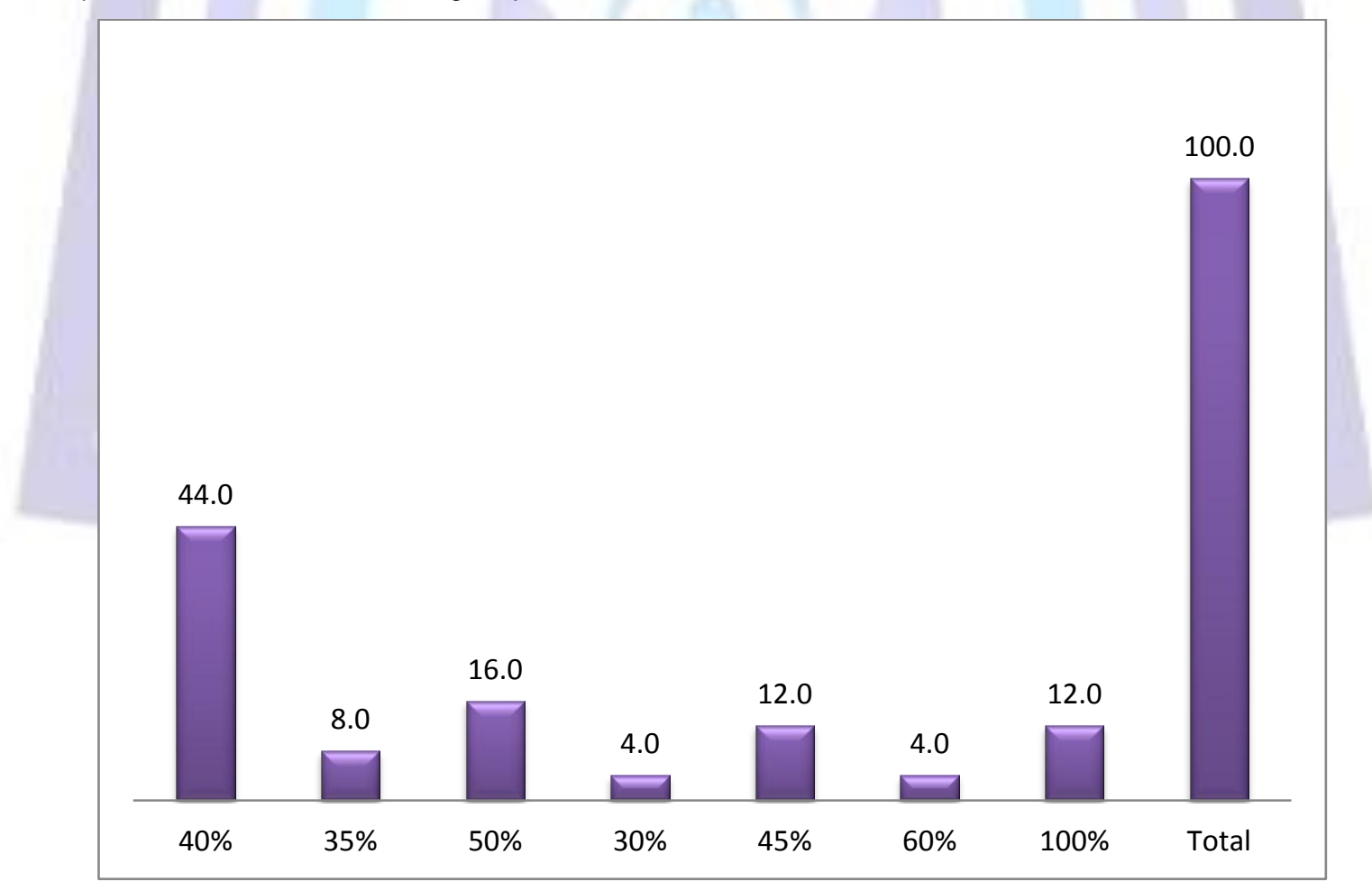

Fig. 7: Access to desalinated water (expectation of the yield increase).

If they would have access to desalinated water $64 \%$ of them are expecting to use $700-750$ cubic meters per dunum yearly (Fig. 8). This is due to $92 \%$ of them are seeing a quality change of water from season to season and especially in summer times. 


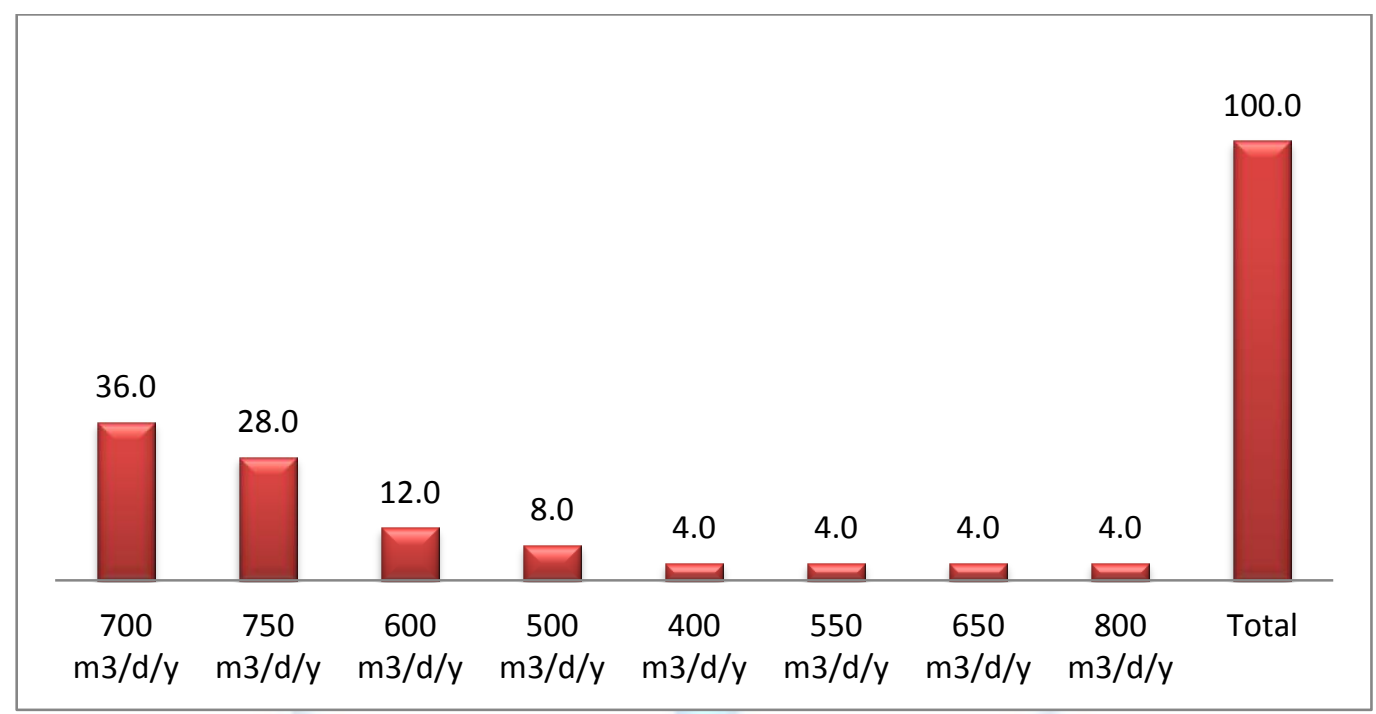

Fig. 8: Access to desalinated water (expected use per year).

The saline water brings different kind of quality changes and this is obvious for them in soil (72\%) and the observation of high sulfur in water as well as the descending of groundwater levels in their wells. The majority of them (84\%) agree to share the cost of the desalinated treatment with other farms and coopering with their neighboring farms.

\section{CONCLUSION}

A field survey of 25 questionnaires was carried out in Jericho area - Palestine for the analyses of the community acceptance towards using desalination units for saline and brackish water for agricultural wells. The SPSS software was used for the analyses of the questionnaire. The cost of one cubic meter of water used for irrigation is different from place to place and range between 0.5 NIS and 1 NIS ( $0.1-0.2$ Euro). Eighty percent of the farms are using water without any treatment that means there is a need of using treatment facilities in order to develop their cropping quality of agriculture. The majority of the farmers expect that the treated cost of the saline water is more expensive than buying fresh water from springs. $88 \%$ of them are looking for a cost of the treated saline water of 0.25 Euro per cubic meter to be accepted for them in regards to standard of living within the Jericho area. 60 percent of them are willing to pay for the 0.2 Euro per treated saline water. If they would have access to desalinated water $64 \%$ of them are expecting to use $700-750$ cubic meters per dunum yearly. The saline water brings different kind of quality changes and this is obvious for them in soil $(72 \%)$ and the observation of high sulfur in water as well as the descending of groundwater levels in these wells. A majority of the farmers (95\%) thinks that the long-term use of saline water will destroy the fertility of the soil as well as the crop agricultural cycle in the area.

The necessity of installing desalination units is emphasized by the fact that most farmers report a decrease in water quality over the years and a resulting decrease in soil quality. This indicates that the current problems with water shortage will become more pronounced in future and will result in decreasing harvest, including a negative influence both for the agricultural market and the farmers themselves. The food prices for inhabitants of the West Bank might increase as a result.

\section{REFERENCES}

[1] Levni E., Goldman M., Hadad A., and Gvirtzman, H., 2008. Spatial delineation of groundwater using deep time domain electromagnetic geophysical measurements: feasibility study, Water Research, Vol. 44, W12404.

[2] Marei A. and Vengosh A., 2001. Sources of salinity in Groundwater from Jericho area, Jordan Valley, Groundwater, Vol. 39., No. 2.

[3] MoA, 2012.Agriculture in Jericho district, report, Ramallah.

[4] PWA, 2012. Jericho Master Plan, Report, Ramallah 